This item was submitted to Loughborough's Research Repository by the author.

Items in Figshare are protected by copyright, with all rights reserved, unless otherwise indicated.

\title{
The politics of the strategic defence and security review: centralisation and
} cuts

PLEASE CITE THE PUBLISHED VERSION

http://dx.doi.org/10.1111/j.1467-923X.2012.02278.x

PUBLISHER

Wiley-Blackwell @ The Authors. () The Political Quarterly Publishing Co. Ltd.

VERSION

AM (Accepted Manuscript)

LICENCE

CC BY-NC-ND 4.0

REPOSITORY RECORD

Dover, Robert, and Mark Phythian. 2019. "The Politics of the Strategic Defence and Security Review: Centralisation and Cuts". figshare. https://hdl.handle.net/2134/9907. 
This item was submitted to Loughborough's Institutional Repository (https://dspace.lboro.ac.uk/) by the author and is made available under the following Creative Commons Licence conditions.

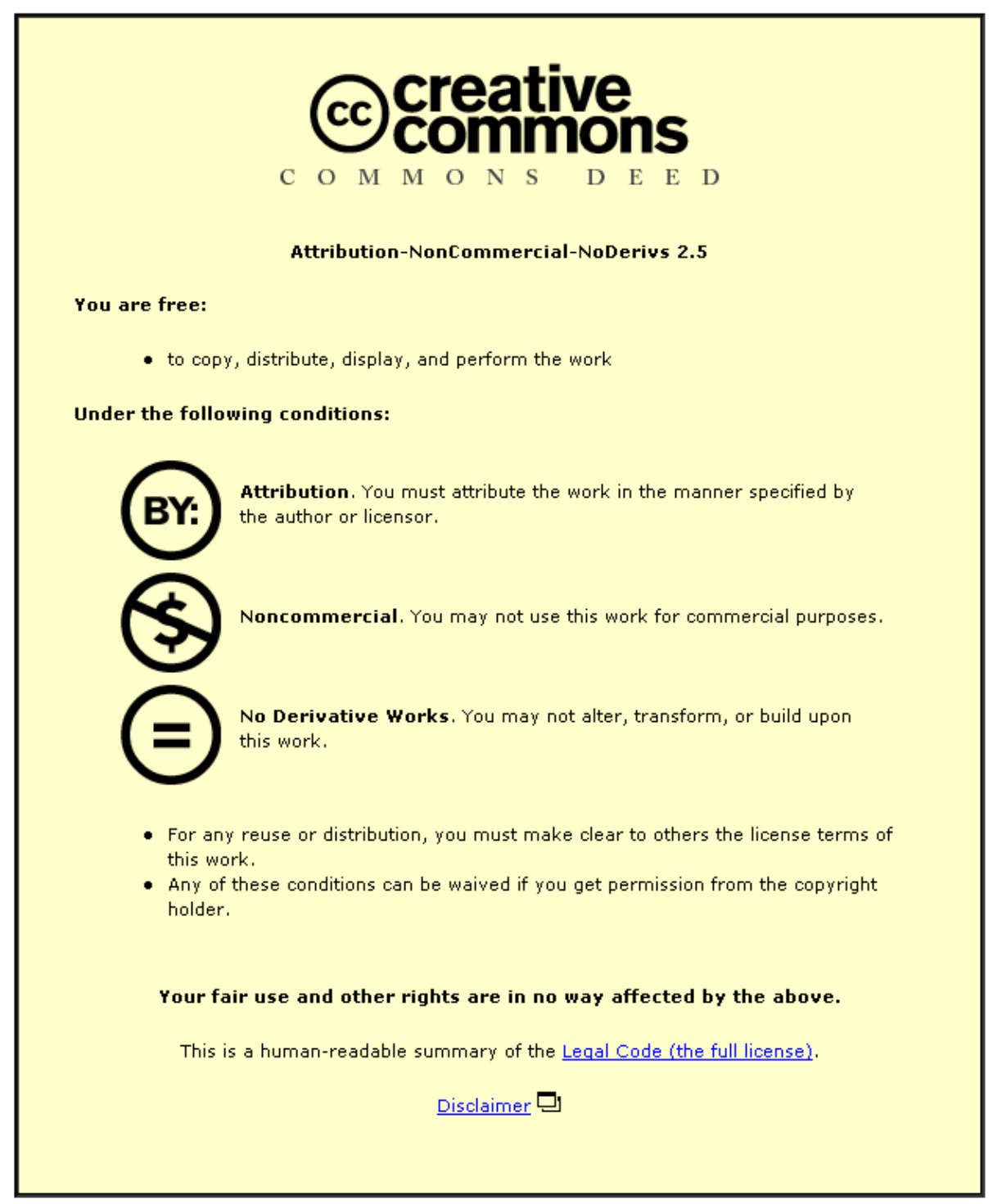

For the full text of this licence, please go to: http://creativecommons.org/licenses/by-nc-nd/2.5/ 


\section{The Politics of the Strategic Defence and Security Review: Centralisation and Cuts}

ROBERT DOVER AND MARK PHYTHIAN

\section{Introduction}

The October 2010 Strategic Defence and Security Review (SDSR), Securing Britain in an Age of Uncertainty - the first substantial defence review in over a decade and the first time that strategy regarding defence, security and intelligence had been formally integrated into a

single review — has inevitably attracted a substantial amount of commentary. ${ }^{1}$ Much of it has focused on individual case studies — be it on a particular equipment programme, the plight of service personnel and their families, or a particular geographical area to be affected by the cuts. We do not propose to go over what is rapidly becoming old ground in this regard. Instead, we examine the politics of the SDSR — that is, the party politics and the political dynamics of the review process, focused on the government's mission to reduce the 'historic deficit', and the centralisation of defence policy. We also examine the political philosophy that is currently being implemented across Whitehall in which defence is emerging as a pathfinding issue area for a new kind of post-industrial bureaucratic environment typified by a 'thin-client' and 'smart customer' function that interacts with industry.

\section{Party politics}

The SDSR was the first major defence review since New Labour's 1998 Strategic Defence Review (SDR), which had been well received by practitioners and commentators alike. The SDR had taken over a year to produce and had taken on board a wealth of external and expert views. Indeed, it was characterised at the time as being the most open defence review ever 
conducted in the United Kingdom. ${ }^{2}$ It was also to a significant degree foreign-policy-led, premised on the idea that there needed to be a strategic refocusing of defence to match up to the post-Cold War realities of a changed geostrategic picture; the Cold War reality had been dangerous but stable, this new reality was dangerous and unstable. In one sense, then, little has changed in the overall framing of defence questions between the SDR and the SDSR: the international system is still dangerous and it is still unstable. After the certainties of the Cold War, the strategic environment in 2010, as in 1998, was characterised by uncertainty.

A key advance made by the 1998 SDR was in the beginning of 'jointery': the connection of joint working structures both within the British armed forces and then between them and their European and NATO colleagues (much of this thinking tied in with the efforts to reinvigorate the European defence projects, which culminated in the 1998 St Malo Accords and the 2000 Nice Treaty). As befitted a government that held very positive attitudes towards the European Union (EU), rather too much emphasis was placed on the EU as a source of force multiplication for Britain—collaborative procurement projects with the EU would produce better equipment at a better price, and joint working would eventually drum out the wasteful duplication of effort across the Union. But the SDR ultimately failed, partly as a result of intra-governmental tension between the respective visions of the Prime Minister and Chancellor of the Exchequer and the centrality of defence to each. Tony Blair saw a strong defence policy as crucial to the establishment and success of the 'New Labour' brand. For example, documents retrieved from Labour party pollster Philip Gould’s dustbin in 2000 included a memo in which Blair had worried about 'asylum and crime, where we are perceived as soft; and asserting the nation's interests where, because of the unpopularity of Europe, a constant barrage of small stories beginning to add up on defence and even issues like Zimbabwe, we are seen as insufficiently assertive. ... We are in fact, taking very tough measures on asylum and crime, Kosovo should have laid to rest any doubts about our strength 
in defence.' Still, Blair worried about seeming 'out of touch' and warned Gould that 'we need to make the CSR [comprehensive spending review] work for defence. Big cuts and you can forget any hope of winning back ground on "standing up for Britain”., 3 In contrast, Brown was always more of a sceptic on defence and, especially as defence cost inflation spiralled during the 2000s, he sought to steadily reduce the defence budget. These twin pressures were exacerbated by the wars in Afghanistan and Iraq, which severely strained the defence budget and hastened the demise of equipment in theatre, with little plan regarding how to replenish or repair stocks.

The origins of many of the problems faced by the SDSR are to be found in the SDR. Expensive equipment procurement decisions (like the aircraft carriers) were flagged up in the SDR, but only resolved in the dying days of the Brown government. Similarly, decisions regarding armoured troop moving vehicles (the 'snatch Land Rover'/IED debate) were botched or avoided during most of the New Labour 2000s, resulting in both anguish to service families and large cost over-runs in trying to sort these problems out in a hurried manner. In the absence of a thorough overhaul of defence management the problem of the Ministry of Defence's (MoD) inflexibility, and unresponsiveness in the face of changing operational and commercial demands was never resolved.

The challenge for the incoming Conservative-Liberal Democrat coalition government in May 2010 was to address the multiple problems bequeathed by New Labour: underinvestment in defence, unfunded defence spending promises, institutional problems in the MoD, the ongoing conflict in Afghanistan and, of course, the record-breaking deficit being carried forward by the Treasury. Whilst a long period of reflection on defence, akin to that which preceded the SDR, was probably necessary, and almost certainly desirable, the coalition government's insistence on prioritising rapid deficit reduction in effect outweighed all other considerations. The MoD was quickly identified as a department ripe for budgetary 
cuts, and from evidence we collected from officials in the MoD, they were under no illusion that the main driver of the review was financial, and their job was to provide the best review in this context.

At the same time, whilst the SDSR was accused of being conducted overly hastily, it is possible to trace its recommendations and intellectual antecedents back through the previous three years' worth of Conservative party announcements and policy developments. It is interesting to note how much of the intellectual framing work of the SDSR had been done prior to the review process commencing. In opposition, the Conservative party had promised a defence review, and had produced their own national security Green Paper in January $2010^{4}$ with the intention that this would provide much of the foundational thinking for the SDSR. Thus the timing of the review, which was to come out just before the Comprehensive Spending Review (CSR), was an attempt to demonstrate how the SDSR was the result of a considerable period of policy gestation and so emphasise its strategic dimension. It is interesting to note, however, that most of the contributing authors to the January 2010 Conservative Green Paper were not party to the government’s review. Furthermore, Secretary of State for Defence Dr Liam Fox’s leaked September 2010 letter to Prime Minister David Cameron, in which he complained that a mishandled SDSR would diminish the party and government's credibility on the issue of defence, can be partly read as a defence of the intellectual work done whilst in opposition. ${ }^{5}$

One notable aspect of the three main parties’ approach to defence at the beginning of the 2010 general election year was the remarkable level of cohesion between them on key points. Whilst the Lib-Dems were, once again, outliers with their pledge to not renew Britain's nuclear deterrent, all three main parties were keen to emphasise the need for a (more or less) strategic defence review, a renewed commitment to servicemen and women who had served the country well in Afghanistan and Iraq (a response to the increasing salience of the 
charge that the military covenant had been breached by the Labour government) and smarter forms of procurement. The Labour government clearly had a record to defend (and their pronouncements were markedly defensive in tone), whilst the Lib-Dems and Conservatives had interesting points of convergence concerning European involvement in British defence, since implemented via the November 2010 Anglo-French Defence Accords. All agreed on the need to reform defence expenditure (with Labour keen to emphasise additional funding during their terms in office, and the Tories and Lib-Dems keen to argue that defence spending was out of control and haphazardly implemented). So, while there were some differences of substance between the three main parties, there were no serious points of departure. This fact helps explain why the initial fears amongst parliamentarians (and the SDSR team) that the coalition government might come under internal strain because of the review were quickly dispelled, particularly once the Lib-Dems stopped pushing on their nuclear preferences.

What we can observe in the aftermath of the review are differences on the minutiae of the specific proposals. One example of this can be found in the Labour party's newfound enthusiasm for codifying the military covenant, which seemed to emerge at the moment when the coalition government had appeared to back out of a pledge by David Cameron to make the covenant legally enforceable. The government were keen not to be caught on the hooks of having established a superior set of standards for one group of citizens, to be able to be held legally accountable for this duty of care and to have established an ill-defined benchmark for the media and their political opponents to constantly reference. Between the three major parties there were, however, no real disagreements about the need to produce defence spending cuts, or about the need to reform the defence sector.

\section{The internal dynamics of the Review: centralisation to the core}


Formally, the SDSR was led by the MoD, but in practice it was led by two senior Cabinet Office civil servants: Hugh Powell and Peter Ricketts, the latter of whom is the British government’s National Security Adviser and a former Chair (2000-2001) of the Joint Intelligence Committee, thus bringing the security dimension, already flagged up by the Conservative party's opposition-era groundwork, foursquare into the review. The MoD’s senior official in the review was said, in private interviews regarding the SDSR process, to have been marginalised during the Review, despite his prominence in delivering the Labour government's defence vision document, Adaptability and Partnership: Issues for the Strategic Defence Review, in February 2010. Even within the MoD’s SDSR unit there were secondees from the Foreign and Commonwealth Office, and an observer from the American Department of Defense, who had been included to avoid a repetition of the situation experienced in 1998 where State and Defense Department officials were informed of the St Malo negotiations but failed to pass the message up the political levels, causing discomfort on both sides of the Atlantic.

The SDSR was conducted almost exclusively by civil servants, with a very strong lead being given by Cabinet Office Minister Oliver Letwin, with only a nod to a very narrow cleavage of London-based policy advisors sufficient enough to provide evidence that consultations had taken place. It is this narrow consultation that has presumably caused the flurry of commentary suggesting alternative routes and different proposals during the Review window and subsequently. ${ }^{6}$ It is certainly emerging as a tactical error. If the Review had been the product of a broader consultative process, the MoD might not have had to fight such a rear guard action subsequently. In the event, the MoD was placed in the unfortunate position of having to maintain the fiction of being the lead department, contain internal dissent, and respond to political and media criticism of the review's outcomes, whilst at the same time managing its own disappointment. As a former party challenger to David Cameron, Defence 
Secretary Fox was also placed in the unenviable position of trying to defend a department he was instinctively close to as well as formally led whilst not openly undermining the new Prime Minister. Some of this tension bubbled to the surface in the private letter Fox had written to Cameron being leaked to the Daily Telegraph. Even worse, traditional-thinking institutions within the MoD had either been scrapped (for example, the Advanced Research Assessment Group), or had been neutered and ordered to brief against its own research (for example, the Defence Concepts and Doctrine Centre, who had provided some of the foundational thinking in the February 2010 Adaptability and Partnership document). So, the MoD, as an institution, failed to advise and inform itself properly-a symptom of the centralisation of powers to the Cabinet Office.

The pressure-cooker effect of restricting the thinking work of the Review to such a small number of officials provoked some asymmetric parliamentary action in an attempt to apply some pressure on the MoD and the government. ${ }^{7}$ Bernard Jenkin's move from the Defence Select Committee (which described the speed of the SDSR as 'startling' ${ }^{8}$ ) to the Public Administration Select Committee (PASC) saw the latter begin to engage in defenceand security-related governance questions. The PASC's major piece of work over the summer 2010 period was its investigation into Who Does Strategy? -interpreted by some close to the SDSR process as a criticism of the absence of strategy in the Review. The PASC published its Who Does Strategy? report three days before the SDSR. Via this timing its point was driven home: the SDSR was a cost-cutting exercise, they were calling for a serious look at Britain’s strategic position, a very different proposition and one ahead of its time in the context of the military action against Libya in early $2011 .^{9}$ Indeed, the entire PASC Strategy report can be read as a sustained critique of the SDSR process and the outgoing Labour government's handling of defence and security policy. Its call for a reorientation of strategic 
thinking, with practical measures on how to engender such thinking, makes for compelling reading.

In the wake of this, the PASC has also established a review into how the civil service is managed, and how it will develop in the post-CSR era. We have been told that this is partly inspired by the case of defence management, where those involved believe that the transformation from a technocrat-led MoD to one subject to short-termism and dislocation to the Cabinet Office and Downing Street risks introducing serious failings into defence public policy making. So, it appears that the decision to keep very close control over the SDSR, contrary to the 1998 experience with the SDR, has generated significant unintended consequences: the squabbling between the three services was unedifying and unfortunate, but a good fight has been put up by parliamentarians (and their unofficial advisers) who are passionate in their alternative vision to the cost-cutting and centralised approach to defence policy.

The question of deficit reduction and financing dominated the work on the SDSR. One of the key problems identified by the SDSR team during the final stages of the Review was the fluid nature of the financial figures being delivered to them. Precise costings from initiatives such as scrapping the Harrier jump-jets are difficult to obtain quickly due to the large number of variables that come with such a programme (such as maintenance, storage, the cost of scrappage itself, etc.). Consequently, as the review process moved towards its October 2010 deadline, the initial cost figures (which had been expressed to the team in terms of ranges of figures) became firmer but in most cases did not provide the anticipated volume of savings. Even post-Review the savings figures on equipment programmes have remained imprecise. The figure published by the government in February 2011, of $£ 12$ billion savings on equipment lines remained largely unevidenced and immune from the sort of scrutiny to which many informed experts wished to subject it. ${ }^{10}$ 
The problems in accurately costing the options put forward by the SDSR have generated the political momentum to revisit the defence budget in 2011, something which is possible through the implementation phase of the SDSR, which is reviewing the Defence Estates, the work on the New Employment Model, and the possibility of revisiting equipment programmes. The problems in accurately costing proposals cannot simply be attributed as a failure on the part of the Review team. It is a phenomenon that is widespread across the $\mathrm{MoD}$, and one we found to be particularly true with regard to the Defence Estates, where the problem of matching up Royal Institute of Chartered Surveyors red-book valuations to reality appears to be an impossible art in an area that looks set for additional deep cuts in 2011.

Large swings in possible capital receipts from asset disposals or foreclosing projects does throw the problem of budgetary planning in the MoD into sharp relief, and with the Royal United Services Institute (RUSI) projecting the shortfall at the end of SDSR at £1-2 billion (and the lower end of these figures were confirmed to us in interview evidence) the need to find additional savings in 2011 is clear, however much the government may be keen to avoid formally reopening the Review. More worrying is the mood music around the implementation phase of the SDSR. In interviews, officials were keen to point towards the desperate measures being taken in the name of deficit reduction. Some suggested a fire-sale of government holdings, whilst others said that capital spend projects with a horizon of ten years or more were now untenable, that existing private finance initiatives (PFIs) deemed to represent poor value for money were now apt to be forcibly renegotiated. In short, radical solutions are plainly still 'on the table', despite the budget surplus for January 2011, which points towards a less gloomy economic environment.

Part of this radical thinking we explore in the final section of this article: the work of Lord Levene’s Defence Reform Unit (DRU) and the design of the Defence Infrastructure Organisation are indicative of a whole new bureaucratic paradigm for the British civil 
service. The Defence Estate (since April 2011, the Defence Infrastructure Organisation), given its size at an estimated $£ 31$ billion comprising 2 per cent of all land in the United Kingdom, is the obvious place to seek further cuts. The review of the defence estates conducted by the Centre for Defence Studies at King's College London was advised by a Downing Street strategist to 'try and find a billion pounds worth of cuts' if it were to gain traction within Number Ten policy circles. The arbitrary figure of $£ 1$ billion is emblematic of how the SDSR and similar reviews in other departments have proceeded: the coalition government's overarching priority has been to reduce the government deficit; secondary policy objectives have fitted around the deficit reduction programme.

\section{Political philosophy: the Defence Reform Unit—delivering transformative change} The DRU was established in August 2010, alongside the SDSR but ostensibly to follow on from the Review, to examine the shape, structure, management and governance of the MoD. The work of the DRU is described by the MoD as one of the Secretary of State's three key priorities (the other two being Afghanistan and the SDSR), and the Steering Group of the unit was chaired by Lord Peter Levene, the former Chief of Defence Procurement. Levene’s formidable reputation in defence circles led to MoD insiders seeing it as prefacing a large round of budgetary cuts and disposals, particularly in the estates. The precise detail of this concern was wrong, but the sentiment is right: Levene's unit has worked as a large engine for change in the MoD and the reforms that it will recommend in the summer of 2011 will fundamentally change the way the Ministry does its work, with the clear potential to ripple out across the rest of Whitehall as well. Levene's unit seeks to create what will amount to a paradigm shift in the way the civil service operates—'delivering the big change now', as one official put it. The DRU has been staffed by MoD civil servants, who took a responsive stance to the unit members, taking instructions and responding to their lead rather than 
bringing MoD institutional memory to the unit. In the event, the DRU has focused on transforming the governance of the MoD, working on the assumption that if it finds a new and workable solution then effective managers will deliver the sort of changes that the new politics of the coalition—with attendant economic savings—demands.

The DRU has taken its transformative role seriously and has put in place a defence infrastructure that officials believe is better able to interact with (as a so-called 'thin-client'), and respond to its commercial partners up to and including these institutions (mainly Defence Procurement at Abbeywood, Bristol, and the new Defence Infrastructure Organisation, DIO) being privatised. The two options being considered by the DRU are the imposition of a privately owned and run interface organisation (which would be unpaid and would derive its money from savings) from existing large-scale providers, or the retention of a 'thin-client' defence client playing an ‘intelligent customer’ role with private industry. Rather than utilising the talents within the MoD, this intelligent customer would seek outside talent and pay them exceptionally well. This sort of private sector thinking has come directly from the DRU steering group.

The thin-client model and the direct privatisation of these organisations would be a significant development in British defence politics, which has seen a large amount of commercial activity coming into the defence realm from the privatisation of core defence research capabilities (DERA to QINETIQ), private facilities management of MoD offices and establishments, and the private provision of defence education and training. The question of how large the market would be for the contract to run an interface organisation also gets to the heart of how viable such a proposal is. If the DIO was replaced or run by a private provider, one suspects that there would not be a great advantage-after all, commercial acumen is only likely to get the organisation so far, and competition is far more important to the logic of privatisation than just placing managers with commercial experience in certain 
positions, even if the intention is to leave an 'intelligent customer function' within the MoD. It is said that the DRU's plan for making such a venture cost-saving is not just through greater efficiency (the sort they naturally expect commercially aware individuals to manage), but also because the organisation will receive no public money for their management activities: the profit for the company will come in making savings that they will be able to keep. It is not clear whether there is the necessary political support for such a venture, and so it is likely that any future privatisation of this function might have to follow the regional contracts model currently run in the MoD, so that there were a greater number of companies bidding for the work, which could then deliver the intended efficiency savings.

The general trend towards industry collaborations permeates all branches of the defence community, from the manager of sensitive sites suggesting private solutions to facilities management at these sites, to the MoD’s consultation website posing questions about what further roles industry might take in the delivery of defence functions. ${ }^{11}$ But the cross-Whitehall proposals in this regard will be even more radical. The work of the so-called 'Shareholder Executive' (SHAREX), which is reviewing the government's land-holdings, is, we are told, taking a radical approach to the future of government land, including to Whitehall itself. Whilst SHAREX is formally separate from the defence estates, this kind of radicalism—or as one official put it 'the desperate measures for desperate times'—clearly has the potential to be applied to other areas of government activity. This is the rewiring of British governance, a further step in the hollowing out of the state: a reduction to a contract negotiating and grant-giving function, whilst the implementation of government functions is entirely held by private or charitable organisations. ${ }^{12}$

The transformation the DRU has sought in the MoD also extends to its division into three teams, covering Political, Strategic and Financial issues; the Armed Forces; and Acquisition and Estates. Officials we interviewed for this article argued that this division may 
work its way through into the MoD proper, as it had gained 'a great deal of traction' within Main Building. Such a division would also greatly assist moves to reduce the size of the MoD and to consolidate downwards onto a smaller staffing footprint. Such a reorganisation of the MoD would genuinely constitute a transformation of its activities. The move towards leaner government bureaucracies that seek to mediate the interface between the government and commercial partners entrenches the dominant position of large private conglomerates that started off life being involved in construction or facilities management contracts, but that would now start to dominate the defence community and public administration in general. Adopting the model that is to be piloted in defence would deliver the year-on-year savings the government says are necessary, but it would also reduce the size of the civil servicesomething that government politicians (of both colours) are wedded to for ideological reasons.

\section{Conclusion}

The SDSR represents an interesting moment politically. There was a surprising amount of cross-party agreement—certainly on the fundamentals, if not the detail of the SDSR— although the government made the error of appearing to U-turn on the issue of bringing the military covenant into law in April 2011, which allowed the covenant to become the issue on which both major parties have fought for the high ground on defence. The Labour party opposition now believes it has a weighty political stick with which to beat the government in the area of defence policy, which they hope will assist in resurrecting their 'strong on defence’ credentials, which Tony Blair worked hard to develop but which were severely damaged by the experiences of Iraq and Afghanistan. The fact that the SDSR was closed and hurried, especially in contrast to the 1998 SDR, sparked widespread dissent within the services (with inter-service rivalry breaking out into open hostility during the Review) and in 
Parliament via the Defence and Public Administration committees, which both made strong attempts to shape the Review's conclusions. This dissent could have largely been avoided had there been a greater sense of consultation —a relative absence all the more curious in the light of the government's pledges on transparency and openness in government.

The SDSR was shaped around the overriding political priority of reducing the government's deficit, rather than around a sense of the strategic need which mortgaged the United Kingdom's defence future to the war in Afghanistan and cyber warfare. The democracy contagion spreading through the Middle East and the military action over Libya in early 2011 has the potential to make the SDSR's fundamental assumptions obsolete in under a year, and the problems of making accurate financial statements and projections on defence also have the potential to derail the Review’s findings. The need to find an additional $£ 1$ billion savings in 2011 neatly links the MoD’s defence estates to the wider review of government property holdings in SHAREX — a body which seems bent on radical cuts. Very large cuts in the defence estates might leave the United Kingdom vulnerable to single points of failure, and because of the problems in generating new capital spending lines, also represent a point of no return.

More widely, and we believe more significantly, the SDSR (in parallel with other government reviews) is heralding a new form of bureaucratic governance in the United Kingdom. The SDSR process provides an excellent example of the way that government functions are being centralised, but as a prelude to privatisation and the shrinking of the state rather than as an end in itself; the control of the Review by the Cabinet Office and Treasury undermines the MoD's claim to expertise and ownership of defence issues, something which had changed between February and October 2010, and can only be put down to the change of administration. The work of the DRU represents a paradigm shift in the way that bureaucratic functions will take place in the future. The DIO has been established with its eventual 
privatisation in mind, and the plans for MoD governance are all geared at providing a thinclient and intelligent customer function (so contract negotiation and management, but no actual implementation done in house), with employees being brought in with commercial experience, rather than re-skilling existing civil servants. This is not so much the shrinking of the state, as the wholesale replacement of the state with private contractors. What happens in defence governance has the clear potential to be replicated across the whole of government, representing a critical loss of the public-service-oriented technical expertise and nimbleness that is vital in fighting wars.

\section{Notes}

\footnotetext{
${ }^{1}$ http://www.direct.gov.uk/prod_consum_dg/groups/dg_digitalassets/@dg/@en/documents/digitalasset/dg_1916 34.pdf?CID=PDF\&PLA=furl\&CRE=sdsr

${ }^{2}$ C. McInnes, ‘Labour’s Strategic Defence Review’, International Affairs, vol. 74, no. 4, 1998, pp. 844-5.

${ }^{3}$ P. Wintour, 'What the memo tells us about Tony Blair’s style of leadership', Guardian, 18 July 2000.

${ }^{4}$ A Resilient Nation: National Security Green Paper, London, Conservative party, January 2010, http://www.conservatives.com/News/News_stories/2010/01/A_Resilient_Nation.aspx

5 'Defence cuts: Liam Fox's leaked letter in full', Daily Telegraph, 28 September 2010, http://www.telegraph.co.uk/news/uknews/defence/8031385/Defence-cuts-Liam-Foxs-leaked-letter-in-full.html

${ }^{6}$ For example, D. Willetts, 'Out on their brigadier', Sun, 14 August 2010; J. Blitz, 'Threats to warships raises national security fears’, Financial Times, 23 August 2010.

${ }^{7}$ J. Kirkup, 'New leak exposes MoD fury at defence cut backs’, Daily Telegraph, 18 November 2010.

${ }^{8}$ Defence Committee, The Strategic Defence and Security Review, First Report, Session 2010-11, HC 345, paragraphs 12 and 14

${ }_{9}^{9}$ Public Administration Select Committee, Who Does Strategy?, First Report, Session 2010-11, HC 713, pp.1920.

10 ' $£ 12$ bn of equipment scrapped in SDSR', Defence Management Journal, 14 February 2011, http://www.defencemanagement.com/news_story.asp?id=15490

${ }^{11}$ Ministry of Defence, Defence Consultations, Defence Support strand, http://defenceconsultations.org.uk/2010/12/20/3-1-2-defence-support-general-and-specific-questions/

${ }^{12}$ Private interview data. For a commentary on these developments in another context, see P. Toynbee, 'NHS turmoil is just the start of Tory ideology run wild', Guardian, 21 February 2011.
} 